\title{
Fish hook injury: an easy removal using the string yank technique
}

\author{
Takashi Watari, ${ }^{1}$ Ichiro Sekine, ${ }^{2}$ Yasuharu Tokuda ${ }^{3}$
}

\begin{abstract}
- Additional material is published online only. To view please visit the journal online (http://dx.doi.org/10.1136/ bcr-2017-222987).

${ }^{1}$ Postgraduate Clinical Training Center, Shimane University Hospital, Izumo, Japan ${ }^{2}$ Emergency Department, Shonan Kamakura General Hospital, Kanagawa, Japan ${ }^{3}$ Muribushi Project for Teaching Hospitals, Okinawa, Japan
\end{abstract}

Correspondence to Professor Yasuharu Tokuda, yasuharu.tokuda@gmail.com

Accepted 11 November 2017 CrossMark

To cite: Watari T, Sekine I, Tokuda Y. BMJ Case Rep Published Online First: [please include Day Month Year]. doi:10.1136/bcr-2017222987

\section{DESCRIPTION}

An embedded fish hook injury is a tough condition for clinical decision-making, as it needs to be determined whether to advance the hook or to pull it out. Patients or their friends usually attempt to remove a fish hook, causing more soft tissue trauma. There are many different sizes and types of fish hooks, and the four main techniques for their removal are (1) retrograde technique for barbless and superficially embedded hooks, (2) needle cover technique for large hooks with a single barb, (3) advance and cut technique for large fish hooks with potential additional trauma and (4) string yank technique for superficially embedded, smallsized to medium-sized fish hooks. ${ }^{1}$ The technique of removal should be selected based on the size and shape of a fish hook and the anatomical condition of the injury. Here, we report a useful technique for primary care physicians, accompanied by an instructional video given in the online supplementary data.

A 62-year-old Japanese nurse suffered from a fish hook injury while fishing, with the hook lodging in her right index finger. She came to a primary care emergency clinic after several unsuccessful attempts for removal by her husband for an hour after the injury. Bleeding from the injury site ceased. We performed the string yank technique (see the video in the online supplementary data).

First, we carefully assessed the depth of the fish hook and the condition of the surrounding tissue before attempting the removal. Next, we tied a tough string, such as silk suture (2-0 gauge) loosely around the middle part of the hook. Then, we stabilised the body of the embedded hook on a flat surface and applied downward pressure to the distant pole of the hook so that it lay against the skin. Finally, while depressing the distal portion of the shaft and keeping it parallel to the underlying skin, we yanked the string quickly and firmly to extract the hook.
Physicians and bystanders should remain out of the hook's line of flight and should always use a protective eye wear, because the hook may come out with significant velocity. The injured site should be cleaned with iodine or hexachlorophene solution before and after the procedure.

This string yank technique is helpful in primary care clinical settings for removing a superficially embedded, small-sized to medium-sized fish hook from skin, since it only cause minimal tissue trauma and rarely requires anaesthesia. However, it cannot be performed on parts of the body that are not fixed (eg, earlobe or eyelid). ${ }^{1-3}$

\section{Learning points}

- String yank technique for fish hook injury can be performed easily in the field and in any clinical setting.

- String yank technique works best when removing a superficially embedded, small-sized to medium-sized fish hook from skin.

Contributors TW and IS cared the patient and recorded the video. All the authors equally contributed to the writing of the manuscript.

Competing interests None declared.

Patient consent Obtained.

Provenance and peer review Not commissioned; externally peer reviewed.

(C) BMJ Publishing Group Ltd (unless otherwise stated in the text of the article) 2017. All rights reserved. No commercial use is permitted unless otherwise expressly granted.

\section{REFERENCES}

1 Gammons MG, Jackson E. Fishhook removal. Am Fam Physician 2001;63:2231-6.

2. Ahmad Khan H, Kamal Y, Lone AU. Fish hook injury: removal by "push through and cut off" technique: a case report and brief literature review. Trauma Mon 2014;19:e17728.

3 Prats $\mathrm{M}, \mathrm{O}^{\prime}$ Connell M, Wellock $\mathrm{A}$, et al. Fishhook removal: case reports and a review of the literature. J Emerg Med 2013;44:e375-80.

Copyright 2017 BMJ Publishing Group. All rights reserved. For permission to reuse any of this content visit

http://group.bmj.com/group/rights-licensing/permissions.

BMJ Case Report Fellows may re-use this article for personal use and teaching without any further permission.

Become a Fellow of BMJ Case Reports today and you can:

- Submit as many cases as you like

- Enjoy fast sympathetic peer review and rapid publication of accepted articles

- Access all the published articles

- Re-use any of the published material for personal use and teaching without further permission

For information on Institutional Fellowships contact consortiasales@bmjgroup.com

Visit casereports.bmj.com for more articles like this and to become a Fellow 